\title{
THE SIMPLE CASE FOR COLLECTIVE ACTION CLAUSES
}

\author{
Jorge Fernández-Ruiz*
}

El Colegio de México, A. C.

(Received 22 July 2004, accepted 3 September 2004)

\begin{abstract}
In this paper we present a model that illustrates in a simple way the benefits of including Collective Action Clauses in sovereign debt contracts. We first show that a situation can arise in which debt forgiveness is Pareto-improving but, due to the existence of multiple creditors, this relief is not granted. We then show that the inclusion of Collective Action Clauses allows the Pareto-improving debt reduction to take place.
\end{abstract}

\section{Resumen}

En este trabajo se presenta un modelo que ilustra en forma sencilla los beneficios de incluir Cláusulas de Acción Colectiva en los contratos de deuda soberana. Primero mostramos que puede presentarse una situación en que, a pesar de que un perdón parcial de deuda produzca mejoras en el sentido de Pareto, este alivio no se produzca debido a la existencia de múltiples acreedores. Posteriormente mostramos que la inclusión de Cláusulas de Acción Colectiva permite que la reducción de deuda socialmente beneficiosa se produzca.

JEL classification: F30, F33, F34

Keywords: Creditor co-ordination, Collective Action Clauses, Sovereign debt

* El Colegio de México. Camino al Ajusco 20. Col Pedregal de Santa Teresa. México, 01000, D.F., Tel. (55) 54-49-30-00, email: jfernan@colmex.mx 


\section{Introduction}

According to received theory, financial flows from abroad can be a powerful instrument in promoting growth and improving welfare in less developed countries. For instance, simple growth models posing the question of whether a welfare-maximizing government in these countries should borrow abroad at a given interest rate usually answer this question with a clear (albeit qualified) yes. There are two main reasons for this answer. First, foreign resources allow the country to take advantage of profitable investment opportunities: the returns from these investments allow for the repayment of the initial debt while leaving a surplus for the country. Without foreign resources, each invested dollar would be subtracted from consumption. Therefore, in a low-income country this would mean that many profitable investment opportunities would be lost.

Foreign borrowing can also increase welfare by allowing to smooth consumption. The country's welfare will be higher if foreign resources allow to increase consumption during bad times in exchange for refraining from some supcrfluous consumption during good times.

Yet, recent developments have linked foreign financial flows to increased instability. Moreover, it has been argued that this instability comes in the form of a new type of crisis, not preventable by following basic recommendations of sound fiscal policies.

We can illustrate this point with the case of Mexico, which has experienced both types of crises. Let us first review one of the typical "old type" debt crisis, originated by expansionary fiscal policies: the crisis that erupted in 1976 as a result of the policies of 1972-1976. It was preceded by two decades of what came to be known as the "stabilizing development", from the mid-fifties to the early seventies, during which Mexico enjoyed sustained growth -with an average annual GDP growth of $6.7 \%$ - and price stability -with prices growing at an average annual rate of $3.8 \%$ - accompanied by small foreign indebtedness. In 1972, however, in an effort to solve social problems that had been left unattended by the stabilizing development ${ }^{1}$ the administration that took office in 1970 started to raise public spending. In 1972 real public spending grew by $21.2 \%$, an increase that was not matched by a raise in taxes, so that it led to an increase in the public deficit. This deficit had averaged a value of $2.5 \%$ of GDP, but grew to almost $5 \%$ in 1972, and reached a maximum of $10 \%$ en 1975 . It was partly financed with public debt and partly with monetary growth. As a result, domestic inflation was above that of Mexico's trade partners which, given the fixed exchange rate regime, led to the overvaluation of the peso. The current account deficit also grew, from $0.2 \%$ of GDP in 1972 to $4.2 \%$ in 1975 . Since the private sector doubted that these combination of policies was sustainable, capital flight followed. Thus, some foreign public borrowing effectively financed capital flight, since part of the borrowed funds ended up as private savings abroad. In August 1976, the peso was devalued by 59\%. Foreign public debt, which was below 7000 billion of dollars in 1972, grew by more than 4000 billion dollars in 1975 and by more than 5000 billion in $1976 .{ }^{2}$

1 See Bazdresch and Levy (1992) for a careful account of policy making in the 1970-1982 period. Our data about this episode come from this source.

2 It is sometimes forgotten the role that international factors also played in this experience: 
Let us now turn to what is often considered an example of the "new" type of crisis, the 1994-1995 crisis. First of all notice that, in contrast to the 19731976 experience, the government was not running an expansionary fiscal policy. It even ran a public surplus in 1992 and 1993 -and a public deficit lower than $1 \%$ of GDP in 1994. Yet, after receiving enormous capital flows from abroad in 1991-1993, Mexico experienced -amid serious political disruptions that caused nervousness among investors- a steady reduction in capital inflows during 1994. International reserves, which stood at 28,000 billion dollars in February 1994 , dwindled to 10,000 billion in early December. ${ }^{3}$ Although some observers ${ }^{4}$ argue that an overvalued peso was an important underlying cause of both this reduction and the weakening of the economy, any possible overvaluation had been eliminated after the December 1994 devaluation. Yet, the events of the previous months had rendered the government illiquid. ${ }^{5}$ With reserves below US 6,000 billion and around US 10,000 tesobonos -short-term dollar indexed debtcoming due in the first quarter of 1995, the government depended on investors' expectations to be able to serve its debt. Despite offering very attractive risk premiums, the government was unable to refinance its short-term debt. This led to a financial panic which could only be stopped when a package of US 52 billion arranged by the US govermment and the IMF was approved. Severe austerity measures followed and GDP fell by $6.9 \%$ in 1995 . This translated in important welfare losses. The urban unemployment rate almost doubled, real average wages fell by 12.5 and, as a consequence of these facts, private consumption also fell -by ${ }^{6} 12.9 \%$ on average and by $45.7 \%$ for durable goods. Also, both private and public investment were severely reduced -the reduction in the first one reached $33.9 \%$ and in the second one $18.9 \%$ - a fact whose consequences would mainly affect future production possibilities.

The Mexican example of 1994-1995 has unfortunately proved not to be an isolated case of a developing country crisis unrelated to imprudent fiscal policy. The East Asian financial crisis is another case in point. Although in 1995 there seemed to be a consensus among international investors that these economies could never fell prey of a Mexican-type crisis, the events of two years later would proved them wrong. The previous success of these economies was reassuring to investors. Indeed, in Malasya, Indonesia and Thailand per capita income increased fourfold over the period 1995-1996, and in Korea grew by a factor of seven. ${ }^{7}$ Furthermore, this growth showed no signs of coming to an end. If we restrict attention to the period between 1985 and 1994, GDP growth averaged $6.8 \%$ in Indonesia, $7.1 \%$ in Malasya, $9 \%$ in Thailand and $8,2 \%$ in Korea. These four economies were not hit by the "tequila effect", since they all grew by more than $8 \%$ in 1995 .

\footnotetext{
around 1973 financial flows to less developed countries grew enormously, closely following the behavior of the oil exporting countries' surplus resulting from the ircrease in oil prices.

3 Radelet and Sachs (1998).

4 Among them Dornbusch and Werner (1994).

5 See Cole and Kehoe (1996) for a formal analysis of this point.

6 Banco de México. Informe Anual.

7 The source for East Asian data is Radelet and Sachs (1998).
} 
Despite their previous success and the lack of imprudent fiscal behavior, these economies suffered a severe financial crisis in 1997, which led to great output losses in 1998. GDP fell by $13.1 \%$ in Indonesia, by $7.4 \%$ in Malasia, by $10.5 \%$ in Tailandia and $6.7 \%$ in Korea.

To reduce instability, two main alternatives have been discussed by policymakers: i) The creation of a bankruptcy-like procedure for dealing with sovereign debt, and ii) the inclusion of Collective Action Clauses in sovereign debt contracts.

Both alternatives reduce creditors' collective action problems when dealing with debtors unable to meet their repayment obligations as originally agreed. An acute case of these problems is the occurrence of a so-called self-fulfilling crisis. These kind of crises occur because an individual creditor's rational choice between refinancing or not an illiquid debtor depends on its expectations on other creditors' choices. If a creditor believes that the rest of the debtor's creditors will not refinance their debts, he will not do it either, for the debtor will be unable to repay if all but one creditor decides not to refinance. By refinancing an illiquid debtor, a creditor with such expectations only assures that he will not have any chance of recovering the funds he lent. Since every creditor is in the same situation, the mere expectation that others will not refinance brings about a crisis. The expectation that the crisis will occur effectively causes its occurrence. It is self-fulfilling.

Collective Action Clauses limit the capacity of individual creditors to veto changes on the conditions of repayment initially agreed upon. Thus, an individual creditor has to accept changes in these initial conditions if a qualified majority of creditors -specified in the contract- approves such changes. It is argued that by facilitating this change in contractual terms, CACs can prevent the occurrence of a liquidity crisis.

It has also been argued that, in contrast to a bankruptcy-like procedure, the use of CACs suffers from two drawbacks to solve collective action problems. ${ }^{8}$ First, they apply only to a specific bond: a qualified majority would be needed to restructure every single bond. Second, since these clauses apply only to new debt, their introduction has to be gradual -as new bonds replace maturing bonds- which means that it may take a long time for their benefits to come into full effect. ${ }^{9}$

In this paper we provide a simple rationale for the inclusion of CACs in debt contracts that does not depend on liquidity issues. In our model there is an initial debt overhang which renders debt forgiveness Pareto-improving. When there are several creditors, however, the only equilibrium is for each creditor to refrain from forgiving debt. The introduction of $\mathrm{CACs}$ makes debt forgiveness possible since it is now an equilibrium that each creditor forgives debt. A typical rationale for CACs is the multiplicity of equilibria that arise due to liquidity problems (Sachs (1995); Gai, Hayes, and Shin (2004)). In our

8 See Eichengreen and Mody (2000a, 200b, and 2003) and Eichengreen, Kletzer, and Mody (2003) for an empirical assessment of these issues.

9 A concern common to CACs and bankruptcy-liked procedures -which we not addressedis that they may have negative consequences on the incentives that sovereign debtors have to repay their debts (Dooley (2000); Dooley and Verma (2001); Gai, Hayes. and Shin (2004)). 
model, in contrast, there are no liquidity problems and without CACs the only equilibrium is not to forgive debt.

The rest of this paper is organized as follows. In section 2 we present a debt overhang model showing that when a country owes debt to a single creditor, this creditor may forgive debt and thus increase both its welfare and the country's welfare. In section 3 we first show that when there are several creditors, the Pareto-improving debt forgiveness will not take place. Next, we show that the inclusion of CACs makes debt forgiveness an equilibrium. In section 4 we conclude.

\section{Debt Forgiveness when There is a Single Creditor}

Consider a debt overhang model in the spirit of Krugman (1988), Sachs (1988) and Fernández-Ruiz (1996). Suppose first that a country has one single creditor to which it owes a large debt $D_{0}$. Furthermore, assume, following FernándezRuiz (1996), that the country's output is given by

$$
y=e+\varepsilon,
$$

where $e$ denotes the country's effort and $\varepsilon$ is a random variable with support $[0, \bar{\varepsilon}]$. Consider now the following game. First, the (single) bank sets the country's debt at a level $D_{1} \leq D_{0}$, that is, it may grant a debt reduction. Next, the country chooses and adjustment effort, e. Finally, output is realized according to equation (1) and the bank receives

$$
R=\min \left[D_{1}, y\right] .
$$

We assume that the agents' Von Neumann-Morgenstern utility functions are given by

$$
C(y-R, e)=(X-R)-g(e),
$$

with $g(0)=0, g^{\prime}(e)>0, g^{\prime \prime}(e)>0$, for the country, and

$$
B(R)=R
$$

for the bank.

To look for the (subgame perfect) equilibrium, consider first the country's adjustment effort decision. The country chooses $e$ to maximize

$$
H(e)=\int_{D_{1}-e}^{\bar{\varepsilon}}\left\{e+\varepsilon-D_{1}\right\} f(\varepsilon) \mathrm{d} \varepsilon-g(e) .
$$

To understand the country's objective function notice that, if $y=e+\varepsilon \leq$ $D_{1}\left(\varepsilon \leq D_{1}-e\right)$, all the output is confiscated by the bank and the country receives nothing. ${ }^{10}$ On the other hand, if $y=e+\varepsilon>D_{1}\left(\varepsilon>D_{1}-e\right)$ the

10 The results would be the same if we assumed that the country always keeps an autonomous output $y_{A}>0$. 
country keeps the amount $e+\varepsilon-D_{1}$. At an optimum, the country's choice satisfies

$$
H^{\prime}(e)=\int_{D_{1}-e}^{\bar{\varepsilon}} f(\varepsilon) \mathrm{d} \varepsilon-g^{\prime}(e)=0
$$

which, by the implicit function theorem, defines " $\mathrm{e}$ " as a function of $D_{1}$ with derivative

$$
\frac{\mathrm{d} e}{\mathrm{~d} D_{1}}=-\frac{-f\left(D_{1}-e\right)}{H^{\prime \prime}(e)}<0,
$$

since $H^{\prime \prime}(e)<0$ is the second order condition for an optimum. Thus, as debt increases, the country is discouraged from exerting effort.

Let us now consider the bank's problem. The bank maximizes its expected revenues

$$
J\left(D_{1}\right)=\int_{D_{1}-e\left(D_{1}\right)}^{\bar{\varepsilon}} D_{1} f(\varepsilon) \mathrm{d} \varepsilon+\int_{0}^{D_{1}-e\left(D_{1}\right)}\left(e\left(D_{1}\right)+\varepsilon\right) f(\varepsilon) \mathrm{d} \varepsilon .
$$

To understand the function $J\left(D_{1}\right)$ notice that, if $\varepsilon>D_{1}-e$, debt will be lower than the country's output, and it will thus be completely repaid. This explains the first term. On the other hand, if $\varepsilon<D_{1}-e$, the country's output will not be enough to repay its debt and repayment will be equal to $y=e+\varepsilon<D_{1}$, which explains the second term. A marginal increase in debt changes the bank's expected profits by

$$
J^{\prime}\left(D_{1}\right)=\int_{D_{1}-e\left(D_{1}\right)}^{\bar{\varepsilon}} f(\varepsilon) \mathrm{d} \varepsilon+\int_{0}^{D_{1}-e\left(D_{1}\right)} e^{\prime}\left(D_{1}\right)+f(\varepsilon) \mathrm{d} \varepsilon .
$$

Equation (9) captures the crucial trade-off that the creditor faces when deciding how much (if any) debt to forgive. The first term on the RHS of (9) is positive, and reflects the fact that an additional unit of debt increases debt repayment under "good" states of nature (states in which $\varepsilon>D_{1}-e$ ). This first term captures the existence of a force that increases the bank's expected profits as debt increases. It thus acts against debt forgiveness. The second term, however, is negative -since $e^{\prime}\left(D_{1}\right)<0$ - and captures the fact that a higher debt discourages the country's productive effort. This second effect favors debt reduction. The optimal level of debt reduction balances these two opposing forces. Debt is optimally set at a level $D^{*}$ given by

$$
J^{\prime}\left(D^{*}\right)=0
$$

We assume that the functions $f(\varepsilon)$ and $g(e)$ and the parameter values are such that

$$
D^{*}<D_{0}
$$

When the inequality in (11) holds and there is only one creditor bank, this bank will provide some debt relief. By setting $D_{1}=D^{*}$, the bank will raise both its expected revenues and the country's welfare. 


\section{Debt Forgiveness when there are Several Creditors}

In this section we first examine the creditors' forgiveness decision when instead of one single bank there are three creditor banks. We show that this multiplicity of creditors hinders debt reduction. Next, we examine the effect of including $\mathrm{CACs}$ in debt contracts. We show that this change allows the efficient granting of debt forgiveness.

\subsection{Debt Forgiveness in the Absence of Collective Action Clauses}

Consider again the setting specified in section 2, but suppose now that there are three creditor banks. This is the simplest case which allows us to examine the benefits of CACs. Assume further for simplicity that each creditor holds one third of the total initial debt $D_{0}$ and let us restrict attention to the case in which each one of them can choose only between the alternatives of reducing its debt to $D^{*} / 3$ or keeping it at $D_{0} / 3$. We have then a game that can be represented as in Figure 1.

In Figure 1, Bank A chooses one of the two rows, Bank B chooses one of the two columns and Bank $\mathrm{C}$ chooses one of the two boxes. Payoffs in each of the cells are given first for Bank A, next for Bank B, and finally for Bank C.

To understand the payoffs in this game, consider for example the case in which Bank A and Bank $\mathrm{C}$ forgive debt -they choose $D^{*} / 3$ - but Bank B does not do so - it chooses $D_{0} / 3$. This corresponds to the cell defined by the upper row, the right column and the upper box. After this forgiveness, the amount of outstanding debt will be equal to $\left(\frac{2}{3} D^{*}+\frac{1}{3} D_{0}\right)$, with creditors $\mathrm{A}$ and $\mathrm{C}$ holding a fraction $\frac{D^{*}}{2 D^{*}+D_{0}}$ of the remaining debt each of them, and creditor B holding a fraction $\frac{D_{0}}{2 D^{*}+D_{0}}$. Thus, Bank A's payoff will be the fraction of the debt it holds times the value of the outstanding debt, $\frac{D^{*}}{2 D^{*}+D_{0}} J\left(\frac{2}{3} D^{*}+\frac{1}{3} D_{0}\right)$. Bank $\mathrm{C}$ will obtain the same payoff as Bank $A$, because it chooses the same strategy. As for Bank B, since it holds a fraction $\frac{D_{0}}{2 D^{*}+D_{0}}$ of the debt, its payoff will indeed be $\frac{D_{0}}{2 D^{*}+D_{0}} J\left(\frac{2}{3} D^{*}+\frac{1}{3} D_{0}\right)$. The explanation for the rest of the cells is similar: each Bank's payoff is simply the fraction of the debt it holds times the value debt.

Figure 1.

Bank C chooses $D^{*} / 3$.

\begin{tabular}{|c|c|c|}
\hline Bank A/Bank B & $D^{*} / 3$ & $D_{0} / 3$ \\
\hline$D^{*} / 3$ & $J\left(D^{*}\right) / 3$ & $\frac{D^{*}}{2 D^{*}+D_{0}} J\left(\frac{2}{3} D^{*}+\frac{1}{3} D_{0}\right)$ \\
& $J\left(D^{*}\right) / 3$ & $\frac{D_{0}}{2 D^{*}+D_{0}} J\left(\frac{2}{3} D^{*}+\frac{1}{3} D_{0}\right)$ \\
& $J\left(D^{*}\right) / 3$ & $\frac{D^{*}}{2 D^{*}+D_{0}} J\left(\frac{2}{3} D^{*}+\frac{1}{3} D_{0}\right)$ \\
\hline$D_{0} / 3$ & $\frac{D_{0}}{2 D^{*}+D_{0}} J\left(\frac{2}{3} D^{*}+\frac{1}{3} D_{0}\right)$ & $\frac{D_{0}}{D^{*}+2 D_{0}} J\left(\frac{1}{3} D^{*}+\frac{2}{3} D_{0}\right)$ \\
& $\frac{D^{*}}{2 D^{*}+D_{0}} J\left(\frac{2}{3} D^{*}+\frac{1}{3} D_{0}\right)$ & $\frac{D_{0}}{D^{*}+2 D_{0}} J\left(\frac{1}{3} D^{*}+\frac{2}{3} D_{0}\right)$ \\
& $\frac{D^{*}}{2 D^{*}+D_{0}} J\left(\frac{2}{3} D^{*}+\frac{1}{3} D_{0}\right)$ & $\frac{D^{*}}{D^{*}+2 D_{0}} J\left(\frac{1}{3} D^{*}+\frac{2}{3} D_{0}\right)$ \\
\hline
\end{tabular}


Figure 1 (continue).

Bank $\mathrm{C}$ chooses $D_{0} / 3$.

\begin{tabular}{|c|c|c|}
\hline Bank A/Bank B & $D^{*} / 3$ & $D_{0} / 3$ \\
\hline$D^{*} / 3$ & $\frac{D^{*}}{2 D^{*}+D_{0}} J\left(\frac{2}{3} D^{*}+\frac{1}{3} D_{0}\right)$ & $\frac{D^{*}}{D^{*}+2 D_{0}} J\left(\frac{1}{3} D^{*}+\frac{2}{3} D_{0}\right)$ \\
& $\frac{D^{*}}{2 D^{*}+D_{0}} J\left(\frac{2}{3} D^{*}+\frac{1}{3} D_{0}\right)$ & $\frac{D_{0}}{D^{*}+2 D_{0}} J\left(\frac{1}{3} D^{*}+\frac{2}{3} D_{0}\right)$ \\
& $\frac{D_{0}}{2 D^{*}+D_{0}} J\left(\frac{2}{3} D^{*}+\frac{1}{3} D_{0}\right)$ & $\frac{D_{0}}{D^{*}+2 D_{0}} J\left(\frac{1}{3} D^{*}+\frac{2}{3} D_{0}\right)$ \\
\hline$D_{0} / 3$ & $\frac{D_{0}}{D^{*}+2 D_{0}} J\left(\frac{1}{3} D^{*}+\frac{2}{3} D_{0}\right)$ & $J\left(D_{0}\right) / 3$ \\
& $\frac{D^{*}}{D^{*}+2 D_{0}} J\left(\frac{1}{3} D^{*}+\frac{2}{3} D_{0}\right)$ & $J\left(D_{0}\right) / 3$ \\
& $\frac{D_{0}}{D^{*}+2 D_{0}} J\left(\frac{1}{3} D^{*}+\frac{2}{3} D_{0}\right)$ & $J\left(D_{0}\right) / 3$ \\
\hline
\end{tabular}

The simplest case for CACs can be made when the efficiency gains from debt reduction are small. Formally, we will examine the case in which although $J\left(D_{0}\right)<J\left(D^{*}\right)$, their difference approaches zero. In this case, we have the following proposition.

Proposition 1. In the absence of Collective Action Clauses, when the gains from debt reduction are small (for $J\left(D^{*}\right)$ sufficiently close to $J\left(D_{0}\right)$ ), the only equilibrium of the debt reduction game is that the three creditors refrain from forgiving debt.

Proof. i) We first prove that it is not a Nash equilibrium that all creditors forgive debt. Suppose to the contrary that it is. Then each creditor obtains $J\left(D^{*}\right) / 3$. If creditor A deviates, it will obtain instead $\frac{D_{0}}{2 D^{*}+D_{0}} J\left(\frac{2}{3} D^{*}+\frac{1}{3} D_{0}\right)$. Thus, creditor A will deviate if

$$
\frac{J\left(D^{*}\right)}{J\left(\frac{2}{3} D^{*}+\frac{1}{3} D_{0}\right)}<\frac{3 D_{0}}{D_{0}+2 D^{*}} .
$$

Notice now that, since $D^{*}<\frac{2}{3} D^{*}+\frac{1}{3} D_{0}<D_{0}$ and $J\left(D_{1}\right)$ decreases for $D_{1}>D^{*}$ (by the concavity of $J\left(D_{1}\right)$ ), then it must be $J\left(D_{1}\right)<J\left(\frac{2}{3} D^{*}+\frac{1}{3} D_{0}\right)$ and, therefore,

$$
\frac{J\left(D^{*}\right)}{J\left(\frac{2}{3} D^{*}+\frac{1}{3} D_{0}\right)}<\frac{J\left(D^{*}\right)}{J\left(D_{0}\right)}
$$

On the other hand, $D^{*}<D_{0}$ implies that

$$
1<\frac{3 D_{0}}{2 D^{*}+D_{0}}
$$

Thus, inequalities (13) and (14) imply that if $J\left(D^{*}\right) / J\left(D_{0}\right)$ is sufficiently close to one -which will be the case if $J\left(D^{*}\right)$ is sufficiently close to $J\left(D_{0}\right)$ - condition (12) will hold. A contradiction. 
ii) Next, we prove that it is not an equilibrium that two creditors forgive debt while the other one refrains from doing so. Suppose to the contrary that this is an equilibrium. Each of the creditors that forgives debt obtains $\frac{D^{*}}{2 D^{*}+D_{0}} J\left(\frac{2}{3} D^{*}+\frac{1}{3} D_{0}\right)$ while, by deviating, would obtain $\frac{D_{0}}{D^{*}+2 D_{0}} J\left(\frac{1}{3} D^{*}+\right.$ $\left.\frac{2}{3} D_{0}\right)$. Thus, a creditor that forgives debt will have an incentive not to do so if condition (15) holds:

$$
\frac{J\left(\frac{2}{3} D^{*}+\frac{1}{3} D_{0}\right)}{J\left(\frac{1}{3} D^{*}+\frac{2}{3} D_{0}\right)}<\left(\frac{D_{0}}{D^{*}+2 D_{0}}\right)\left(\frac{2 D^{*}+D_{0}}{D^{*}}\right) .
$$

Now, since $D^{*}<\frac{2}{3} D^{*}+\frac{1}{3} D_{0}<\frac{1}{3} D^{*}+\frac{2}{3} D_{0}<D_{0}$, and $J\left(D_{1}\right)$ is decreasing for $D>D^{*}$, we have that $J\left(D_{0}\right)<J\left(\frac{1}{3} D^{*}+\frac{2}{3} D_{0}\right)$ and $J\left(\frac{2}{3} D^{*}+\frac{1}{3} D_{0}\right)<J\left(D^{*}\right)$. Thus,

$$
\frac{J\left(\frac{2}{3} D^{*}+\frac{1}{3} D_{0}\right)}{J\left(\frac{1}{3} D^{*}+\frac{2}{3} D_{0}\right)}<\frac{J\left(D^{*}\right)}{J\left(D_{0}\right)}
$$

On the other hand, $D^{*}<D_{0}$ implies that

$$
1<\left(\frac{D_{0}}{D^{*}+2 D_{0}}\right)\left(\frac{2 D^{*}+D_{0}}{D^{*}}\right) .
$$

But, conditions (16) and (17) imply that if $J\left(D^{*}\right)$ is sufficiently close to $J\left(D_{1}\right)$ -and thus $J\left(D^{*}\right) / J\left(D_{1}\right)$ is sufficiently close to one- condition (15) will indeed hold. A contradiction.

iii)We now prove that it is not an equilibrium that one creditor forgives debt while the other two creditors refrain from doing so. Assume the contrary. Then, the creditor that forgives debt obtains in equilibrium $\frac{D^{*}}{D^{*}+2 D_{0}} J\left(\frac{1}{3} D^{*}+\right.$ $\left.\frac{2}{3} D_{0}\right)$. If this creditor deviated and refrained from forgiving debt it would obtain $J\left(D_{0}\right) / 3$. Thus, this creditor will deviate from its equilibrium strategy if condition (18) holds:

$$
\frac{J\left(\frac{1}{3} D^{*}+\frac{2}{3} D_{0}\right)}{J\left(D_{0}\right)}<\frac{D^{*}+2 D_{0}}{3 D^{*}}
$$

Now, since $D^{*}$ is the debt level that maximizes $J(\cdot), J\left(\frac{1}{3} D^{*}+\frac{2}{3} D_{0}\right)<J\left(D^{*}\right)$ and thus

$$
\frac{J\left(\frac{1}{3} D^{*}+\frac{2}{3} D_{0}\right)}{J\left(D_{0}\right)}<\frac{J\left(D^{*}\right)}{J\left(D_{0}\right)} .
$$

On the other hand, $D^{*}<D_{0}$ implies that

$$
1<\left(\frac{\frac{1}{3} D^{*}+\frac{2}{3} D_{0}}{D^{*}}\right) .
$$

Now, (19) and (20) imply that if $J\left(D_{1}\right)$ is sufficiently close to $J\left(D^{*}\right)$-and thus $J\left(D^{*}\right) / J\left(D_{1}\right)$ is sufficiently close to one- condition (18) indeed holds. A contradiction. 
iv)We finally prove that it is an equilibrium that all creditors refrain from forgiving debt. In equilibrium each creditor obtains $J\left(D^{*} / 3\right)$. If a creditor forgave debt it would instead obtain $\frac{D^{*}}{D^{*}+2 D_{0}} J\left(\frac{1}{3} D^{*}+\frac{2}{3} D_{0}\right)$. Thus, the creditor will not deviate from its equilibrium strategy if condition (18) above holds. We know from (19) and (20) that this will be the case for $J\left(D^{*}\right)$ close to $J\left(D_{1}\right)$. Since no creditor has incentives to deviate from its equilibrium strategy we indeed have an equilibrium.

\subsection{Introduction of Collective Action Clauses}

Assume now that the CACs are in place. To simplify the exposition, suppose that these Clauses specify that when a simple majority of debt-holders (two out of three in our case) agree to forgive debt, this reduction will also apply to the dissenting debt holders (the remaining one in our case). Formally, each debt holder chooses between keeping the debt level at its original level $D_{0} / 3$ or reducing it to the optimal level $D^{*} / 3$. This change of rules changes in turn the debt reduction game from the one represented in Figure 1 to the one represented in Figure 2.

Again, in Figure 2 Bank A chooses one of the two rows, Bank B chooses one of the two columns and Bank $\mathrm{C}$ chooses one of the two boxes. Payoffs in each cell are given first for Bank A, then Bank B, and then Bank C.

The key difference with Figure 1 is that the presence of CACs leads to different payoffs. When at least two banks choose to reduce debt (choose $D^{*} / 3$ ) then this reduction is applied to all debt, so that the outstanding debt is $D^{*}$ and each bank receives $J\left(D^{*}\right) / 3$. When less than two banks vote for debt reduction, the payoffs are as in Figure 1.

Figure 2.

Bank C chooses $D^{*} / 3$.

\begin{tabular}{|c|c|c|}
\hline Bank A/Bank B & $D^{*} / 3$ & $D_{0} / 3$ \\
\hline$D^{*} / 3$ & $J\left(D^{*}\right) / 3$ & $J\left(D^{*}\right) / 3$ \\
& $J\left(D^{*}\right) / 3$ & $J\left(D^{*}\right) / 3$ \\
& $J\left(D^{*}\right) / 3$ & $J\left(D^{*}\right) / 3$ \\
\hline$D_{0} / 3$ & $J\left(D^{*}\right) / 3$ & $\frac{D_{0}}{D^{*}+2 D_{0}} J\left(\frac{1}{3} D^{*}+\frac{2}{3} D_{0}\right)$ \\
& $J\left(D^{*}\right) / 3$ & $\frac{D_{0}}{D^{*}+2 D_{0}} J\left(\frac{1}{3} D^{*}+\frac{2}{3} D_{0}\right)$ \\
& $J\left(D^{*}\right) / 3$ & $\frac{D^{*}}{D^{*}+2 \bar{D}_{0}} J\left(\frac{1}{3} D^{*}+\frac{2}{3} D_{0}\right)$ \\
\hline
\end{tabular}


Figure 2 (continue).

Bank $\mathrm{C}$ chooses $D_{0} / 3$.

\begin{tabular}{|c|c|c|}
\hline Bank A/Bank B & $D^{*} / 3$ & $D_{0} / 3$ \\
\hline$D^{*} / 3$ & $J\left(D^{*}\right) / 3$ & $\frac{D^{*}}{D^{*}+2 D_{0}} J\left(\frac{1}{3} D^{*}+\frac{2}{3} D_{0}\right)$ \\
& $J\left(D^{*}\right) / 3$ & $\frac{D_{0}}{D^{*}+2 D_{0}} J\left(\frac{1}{3} D^{*}+\frac{2}{3} D_{0}\right)$ \\
& $J\left(D^{*}\right) / 3$ & $\frac{D_{0}}{D^{*}+2 D_{0}} J\left(\frac{1}{3} D^{*}+\frac{2}{3} D_{0}\right)$ \\
\hline$D_{0} / 3$ & $\frac{D_{0}}{D^{*}+2 D_{0}} J\left(\frac{1}{3} D^{*}+\frac{2}{3} D_{0}\right)$ & $J\left(D_{0}\right) / 3$ \\
& $\frac{D^{*}}{D^{*}+2 D_{0}} J\left(\frac{1}{3} D^{*}+\frac{2}{3} D_{0}\right)$ & $J\left(D_{0}\right) / 3$ \\
& $\frac{D_{0}}{D^{*}+2 D_{0}} J\left(\frac{1}{3} D^{*}+\frac{2}{3} D_{0}\right)$ & $J\left(D_{0}\right) / 3$ \\
\hline
\end{tabular}

This configuration of payoffs leads to the following result:

Proposition 2. In the presence of Collective Action Clauses, it is an equilibrium of the debt reduction game that all creditors forgive debt.

Proof. When all creditors forgive debt, each one of them gets $J\left(D^{*}\right) / 3$. Now, if a creditor deviates from this strategy and refrains from forgiving debt, there will still be two out of three creditors granting debt reduction. The CACs will imply that the debt of this dissenting creditor will also be reduced to $D^{*} / 3$. Thus, the dissenting creditor will still get $J\left(D^{*}\right) / 3$, showing that he has no incentive to deviate from his initial strategy.

Remark. In the presence of CACs, there is also an equilibrium in which all creditors refrain from forgiving debt. To see why, notice that when all creditors refrain from forgiving debt, if only one of them deviates and forgives debt the CACs will not imply that debt reduction is imposed on the other two creditors.

In light of the fact that debt reduction cannot emerge as the outcome of the game -as established in Proposition 1- in the absence of CACs, Proposition 2 provides a simple rationale for its inclusion: they turn efficient debt reduction into an equilibrium outcome.

\section{Conclusion}

In this paper we have presented a model that illustrates in a simple way the benefits of including Collective Action Clauses in sovereign debt contracts. Our model does not rely on the existence of liquidity problems, but on the existence of a "debt overhang" as in Krugman (1988) and Fernández-Ruiz (1996). We first have showed that a situation can arise in which debt forgiveness is Paretoimproving. We then have shown that when there are several creditors this debt forgiveness may not happen since, for some parameter values, the only equilibrium of the game is for all creditors to refrain from forgiving debt. Next, we have analyzed again the situation with multiple creditors, but this time 
assuming that the debt contracts contain Collective Action Clauses. These Clauses restore the possibility of debt forgiveness, since it is an equilibrium of the game that all creditors grant relief.

\section{References}

Banco de México. Informe Anual. 1995.

Bazdresch, C. and S. Levy (1992). Populism and Economic Policy in Mexico. 1970-1982. In R. Dornbusch and S. Edwards. The Macroeconomics of Populism in Latin America. The University of Chicago Press. Chicago.

Cole, H. and T. Kehoe (1996). A Self-fulfilling Model of Mexico's 1994-1995 Debt Crisis. Journal of International Economics, 41.

Dooley, M. (2000). Can Output Losses Following International Financial Crises be Avoided ? NBER, Working Paper, Num. 7531.

Dooley, M. and S. Verma (2001). Rescue Packages and Output Losses Following Crises. NBER, Working Paper, Num. 8315.

Dornbusch, R. and A. Werner (1994). Mexico: Stabilization, Reform, and No Growth. Brookings Papers on Economic Activity, 1.

Eichengreen, B., K. Kletzer, and A. Mody (2003). Crisis Resolution: Next Steps: IMF, Working Paper.

Eichengreen, B. and A. Mody (2000a). Would Collective Action Clauses Raise Borrowing Costs? NBER, Working Paper, Num. 7458.

Eichengreen, B. and A. Mody (2000b). Would Collective Action Clauses Raise Borrowing Costs? An Update and Extension. World Bank Research, Paper Num. 2363.

Eichengreen, B. and A. Mody (2003). Is Aggregation a Problem for Sovereign Debt Restructuring. American Economic Review, forthcoming.

Fernández-Ruiz, J. (1996). Debt and Incentives in a Dynamic Context. Journal of International Economics, 41.

Furman, J. and J. Stiglitz (1998). Economic Crises: Evidence and Insights from East Asia. Brookings Papers on Economic Activity, 2.

Gai, P., S. Hayes, and H. Shin (2004). Crisis Costs and Debtor Discipline: The Efficacy of Public Policy in Sovereign Debt Crises. Journal of International Economics, 62, 245-262.

Krueger, A. (2001). International Financial Architecture for 2002: A New Approach to Soveregin Debt Restructuring. American Enterprise Institute, Washington.

Krugman, P. (1988). Financing vs. Forgiving a Debt Overhang. Journal of Development Economics, 29.

Radelet, S. and J. Sachs (1998). The East Asian Financial Crisis: Diagnosis, Remedies, Prospects. Brookings Papers on Economic Activity, 1.

Sachs, J. (1988). The Debt Overhang of Developing Countries. En De Macedo and Findlay (Eds.). Diaz Memorial Volume. Wider Institute, Helsinki.

Sachs, J. (1995). Do We Need an International Lender of Last Resort. Frank D. Graham Lecture in Princeton University. April. 